\title{
Growth Mindset of Quality Management in an Islamic School
}

\author{
Denny Kodrat ${ }^{1 *}$ \\ ${ }^{1}$ Sekolah Tinggi Bahasa Asing Sebelas April , Sumedang, Indonesia
}

\section{ARTICLE INFO}

\section{Keywords}

Mindset, Total Quality

Management, Education,

Improvement

\section{*Correspondence \\ denny.kodrat@gmail.com}

\section{Article History}

Received 20 January 2020

Accepted 7 March 2020

Published on-line 8 March 2020

\section{ABSTRACT}

The work aims at clarifying how the growth mindset plays a vital role in quality management at the Islamic school. As an active response towards industrial revolution 4.0, an Islamic school is faced with complex external challenges, from the issue of radicalism, anti-multiculturalism to tight competitiveness with the public (general) school. An Islamic school tends to feel satisfied with the output that school graduates are Al-Quran memorizers, while the school seems to ignore the input and process. At the same time, the government has stipulated the regulation dealing with national education standards being followed by educational stakeholders. Eight national educational standards become a reference in Islamic school quality management. The school is urged to provide human resources to meet the requirements. Library research was intensively carried out. Growth mindset becomes an essential basis in Islamic schools in developing quality concern as a total quality management philosophy requires continuous improvement tradition. Without a growth mindset in quality management at Islamic schools, quality improvement and school competitiveness are difficult to reach. This manuscript employed some theoretical references, such as mindset and quality.

\section{INTRODUCTION}

Facing a fourth (4.0) wave of industry revolution, an Islamic school is ready to get by local and global challenges. Radicalism issue, along with terrorism, intolerant and anti-multiculturalism even anti-Pancasila (Indonesia state ideology), tightly stigmatizes Islamic schools. The challenges put an Islamic school in two situations, (1). Islamic schools where teach Islamic values (kaffah), which may be regarded as a radical school in the future or (2). Moderate Islamic schools which strictly sort a teaching material. These options make a dogmatic Islam and secular Islam (Kurniawan and Mahrus, 2011). Furthermore, the mainstream of freedom is easily accessed and massive through the gadget, which can be a bad influence on students' mindsets and attitudes. This is a real challenge. Islamic schools are encouraged to solve the local problem, as Islamic vision in education which can make human not only as information objects and be influenced (Mardjun, 2007), but also a productive and creative human who can empower their thinking process in surfing towards the unpredictable situation (Kodrat, 2019).

On the other hand, a global challenge really exists. Easy accessibility of information tends to lead students to follow global trends uncontrollably (Staiou, 2006). Fashion trends happening in Europe and America are easily noticed by students in Indonesia through their handphone once. Global ideas can influence students and stakeholders of Islamic education thoughts. It will change the vision of Islamic schools that they manage. At least, they will come to the option whether they keep the vision of pure Islamic school or improve their lead to be moderate or secular.

The people demand for Islamic school competition, especially school graduates, becomes a hot issue. The domination of public schools in the National Examination (NE) scores can be observed in the result of 2019 NE. The best three senior high schools were SMA Negeri Unggulan Husni Thamrin, with average score 91.68, SMA Santa Ursula BSD, Banten (91.09), and SMA Kristen 1 Penabur, Jakarta $(90.98)^{1}$. In junior high schools, the big three schools were SMP Negeri 5 Yogyakarta (95.26), SMP Negeri 4 Pakem, Yogyakarta (94.22), and SMP Negeri 115 Jakarta (93.78) ${ }^{2}$. NE score is one of the indicators that quality and competition of Islamic schools should be upgraded, besides Islamic schools need to anticipate local and global challenges.

In people's concerns, particularly Muslim families, it seems that people are interested in sending their children to Islamic schools. The growth of Islamic schools has been developing day by day from pesantren (non-formal Islamic boarding school), homeschooling to schools of Al-Quran memorizers (tahfidz), completing the other Islamic schools. Jaringan Sekolah Islam Terpadu

${ }^{1}$ https://www.liputan6.com/news/read/3993360/ini-daftar-100-sma-terbaik-berdasarkan-hasil-un-2019

2https://edukasi.kompas.com/read/2019/06/11/10151351/daftar-15-smp-negeri-terbaik-nasional-peraih-un-2019-tertinggi?page=all

(C) 2020 by the authors; Association of Indonesian Moslem Scholar, Hannover, Germany. This is an Open Access article distributed under the terms of the Creative Commons Attribution-ShareAlike 4.0 International License. (https://creativecommons.org/licenses/by-sa/4.0/), which permits unrestricted use, distribution, and reproduction in any medium, provided the original work is properly cited. 
(JSIT) can be taken as a good example. In 1993, JSIT had only five schools. Then, it developed to be 426 units in 2003. In 2017, it became 2418 units $^{3}$.

The effort to improve the institution's competition and quality should be a top priority. One of them is to introduce and maintain the growth mindset in organizing Islamic school quality. Salis (2002) states that quality cannot happen coincidentally and by accident. It should be planned and by design. By good governance, an Islamic school is expected to anticipate a new challenge, including the best top three in NE. The manuscript will then uncover the importance of the growth mindset in quality management.

\section{RESEARCH METHOD}

This review was based on literature study about quality management in an islamic school. Analysis was done based on the facts collected from the literatures, considering consistent facts found in the articles. Conclusion was done based on these facts after analysis completed.

\section{RESULTS AND DISCUSSION}

3.1 Growth Mindset versus Fixed Mindset

The basic difference between a growth mindset and fixed mindset is how to see reality. A fixed mindset believes that everything cannot be changed, while the growth mindset sees differently (Dweck, 1999, 2006; Mueller \& Dweck, 1998). Fixed mindset refuses constructive feedback (Saunders, 2013) event tends to blame external factors (Dweck, 2006). So, failure is due to an external, not internal factor.

From a fundamental perspective, a growth mindset has a belief that success can be achieved by learning. Constructive feedback can become as a motivation to improve themselves and not to blame external factors when they fail (Saunders, 2013). Another character of the growth mindset has persistence in obtaining a determined vision (Dweck, 1999, 2006). A fixed mindset person will be a passenger, and growth mindset will be a driver in every change (Kasali, 2015). In addition, there are different mentalities between a driver and a passenger, as described in Table 1.

Tabel 1. The Comparison of Passenger Mentality and Driver Mentality (Kasali, 2015)

\begin{tabular}{lll}
\hline No & \multicolumn{1}{c}{ Passenger Mentality } & \multicolumn{1}{c}{ Driver Mentality } \\
\hline 1 & Satisfy with a present condition. & Not satisfied with a present condition (status quo) \\
2 & Not happy with a new challenge. & Happy with new challenges, explore new opportunities. \\
3 & Let people solve their problems. & Solve the problems together, inspire other people. \\
4 & Wait for an order and say "ready." & Lead with the question, improve the passenger's way of thinking. \\
5 & Afraid of facing the problem and making mistakes. & Excellent to make small mistakes and take a risk. \\
6 & I love a career position or power very much. & Show a clear way, together with people who are different opinions. \\
7 & Led by an autopilot. & Led by creative thinking. \\
8 & Show up what has already been achieved. & Always learn new things. Love a good change, humble and empathy. \\
9 & Make an organization as a vehicle for self-interest. & Work by heart, love people, maintain good relation, care. Free an \\
& & organization from self-interests. \\
\hline
\end{tabular}

In the context of quality management in Islamic schools, a growth mindset plays an essential role for the school's stakeholders. A teacher as a first layer service officer has an essential function in giving service excellent towards students as an external customer (Salis, 2002). A teacher with a growth mindset will be avoided from what is so-called "CEO disease" (Dweck, 2006). One of the obvious symptoms is feeling satisfied with what they already have without learning something new. A new challenge is regarded as a burden; at the same time, they never build their capacity in facing the problem. As a quality awareness in society, some regulations are requested schools to care about school management in quality standards, such as Government Bill No. 66/2010 about the Government Bill No. 17/2010 about Education Management and Operation, National Education Minister Bill No. 63/2009 about Quality Assurance System. The regulation demands a school not only thinking about the main job and institution obligation. Moreover, a school should make sure all processes are based on a quality standard. Then, a present situation is not considered as a static event and never change. However, it can suddenly happen, change drastically, and keep adjusted with people's demand. It is because quality is for costumer and stakeholder's purpose (Arcaro, 2007; Kodrat, 2019). This is the reason a school leader of Islamic school needs a growth mindset. Even, it is commanded by Allah as He said.

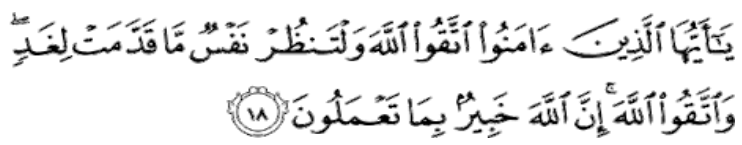

O you have believed, fear Allah. And let every soul look to what it has put forth tomorrow - and fear Allah. Indeed, Allah is acquainted with what you do

In this verse, it is stated that every person needs to care about what will happen at the future. The future problems should be solved with new solutions, not the old or similar solution. The issues should be approached with a growth mindset, anticipating a new possible problem. Without a growth mindset, a new obstacle is difficult to overcome.

In another verse, Allah Swt said

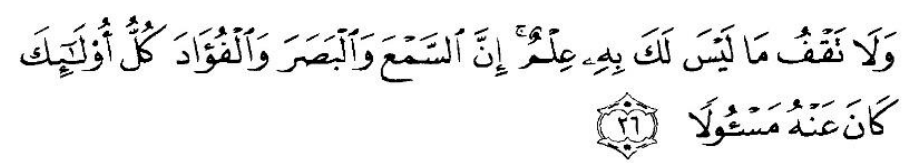

${ }^{3}$ https://khazanah.republika.co.id/berita/dunia-islam/islam-nusantara/17/07/15/ot3za2313-pesat-perkembangan-sekolah-islam-terpadu).
${ }^{4}$ Q.S Al-Hasyr verse 18 
And do not pursue that of which you have no knowledge. Indeed, the hearing, the sight, and the heart-about all those (one) will be questioned. ${ }^{5}$

In verse, Allah Swt orders humans to learn continuously, so they have knowledge and responsibility with all activities based on knowledge. Only with a growth mindset, someone will be encouraged to learn for his own interest and career. In the process of facing the challenges, someone with a growth mindset will embrace a challenge with a strong belief that he is tough in solving the problems. The obstacles will not weaken them because success is not determined by someone else. Feedback, critics, and someone's success are considered as blessings and lessons (Dweck, 2006). However, someone with a fixed mindset tends to avoid the challenges, worries to fail, and bullied by other people. Someone else's success becomes a threat, feeling inconvenient if people give them negative feedback (Dweck, 2008).

Growth Mindset becomes an essential element for an Islamic school's leader in learning about total quality management, as Salis (2002) suggested, arranging vision which is in line with a quality achievement, as an effort in handling unpredicted problems which can probably happen anytime. Feedback and continuous improvements become a quality principle and an unseparated part of a school leader and stakeholders.

\subsection{Basic Concept of Quality in Education}

People see quality in education in the artificial surface; it is the only related with output (graduates), while input and process are ignored. In the concept of total quality management, a quality requires a full service in every part of input, process, and output 6 . Crosby (1979) states that quality as conformance to requirement. Hence, in the context of quality management at school, there are two important aspects that should be considered, they are (1). A school should respond and delight customer's needs; and (2). A school should fulfill not only student's needs but also people's demands. The two aspects can be analyzed from the perspective of process, fitness, and product. From the process perspective, a quality achievement can be observed from effective and efficient aspects. From the fitness perspective, quality can be seen from the completion of the institution and academic goals, including the school graduates who are accepted in the next level of education or if they work, people feel satisfied with their competences. From a product perspective, quality can be obtained from a qualified graduate. Parents and people in society satisfy with the outstanding capabilities. Students are able to use science and technology based on their needs, getting a good and prospective job, and create employment.

A quality paradigm believes that a good output is the result of good governance of input and process, the successful design which is operated based on an accurate plan and on the track, not by accident principle or without guidance. Therefore, Salis (2002) insists on an available standard in quality management. The standard is used to keep the customers (students and parents) feeling satisfied with the given services and products. Even customer satisfaction should be beyond level what they have expected. The government sets the minimum educational standards with the government regulation No. 13/2015 about the second revision of the regulation No. 19/2005 about national education standard, and also the minister regulation no. 3/2020 about higher school national educational standards. Educational service in Indonesia should at least fulfill or go beyond what the standards stated in the regulations.

From the legal aspect, if Islamic schools want to run the management process of formal education, then they should follow the regulation of educational standards. In other words, the eight standards of education, from the standard of output competence, content, process, management, teachers and staff, budget and facilities, to the evaluation standard, should meet the minimum required standards that are determined by the government. Islamic schools should not only think about how to produce the AlQuran memorizers, without considering satisfaction aspects of students and parents in the process elements like educational services, fitness which concerns with institution vision achievement and product elements which focus on the acceptance output competence in society.

The government standards should be obeyed by Islamic schools since the government position as one of the educational stakeholders and part of society. Moreover, schools' accreditation performed by a professional association or school accreditation boards is external quality assurance and can be used by people to evaluate schools' quality. So, Islamic schools should take educational standards as guidance in the school's quality management.

An Islamic school should seriously make a strategic plan and commit to realizing the strategic plan which considers the institution's vision, educational standards, and customers' satisfaction. The Islamic school should consider quality principles, as Crosby (1979) suggested, especially the aspect of process, fitness, and product. A road map of Islamic schools in obtaining their advantages can be made based on the existing challenges of national and global education. Islamic schools should concern with their distinctive benefits, such as they are outstanding in creating Al-Quran memorizers and have qualified academic and information technology competence.

In the 4.0 era, quality can be realized with the use of technology. The management information system supplies big data connected with resources. Planning, doing, and evaluating data can be efficiently reached and help in decision making. Then, the sense of concern in quality can be seen in how Islamic schools use the management information systems. The sufficient data supply through a management information system can influence decision making quality and improvement (Staiuo, 2006). It makes a strategic plan is easy to get. In brief, an Islamic school road map in realizing a strategic plan is a part of the responsibility sense of Islamic schools towards quality management.

\subsection{Total Quality Management}

Total Quality Management (TQM) has been widely adopted in industry or factory business. The philosophy elements of TQM, then, are used in education. It becomes one of the approaches in management, which puts a quality issue as a big goal. The character of TQM is the involvements of all school elements. Some keywords in TQM are customers' focus, top-level leadership, measurement, and continuous improvements. Arcaro (2007) states some principles in TQM. They are:

1. Customers' focus. Students are external customers who directly get educational services, and so do the parents, people, and government. Teachers and staffs are internal customers at schools. Then, if the institution treats teachers excellently, the teachers' excellent service towards students is improved. The policy, program, and available facilities are focused on customer satisfaction.

\footnotetext{
${ }^{5} \mathrm{QS}$. Al Isra' ayat 36

${ }^{6}$ https://www.uin-malang.ac.id/r/150201/akar-masalah-rendahnya-mutu-pendidikan.html
} 
2. Commitment. Quality is not only written on documents or school's billboards. Quality is a commitment and promise which should be realized. School activities do not stick on daily activities or business as usual. It should think about the continuous improvements as a spirit of TQM.

3. Total involvement. Quality is everyone's responsibility, not only the leader. All parts of the organization should care about a quality in their activities.

4. Measurement. A quality achievement will be easier if it is based on quantitative analysis. The activity is measured and compared in every situation and time and is observed how far the quality is achieved.

5. Continuous improvement. In a management cycle, an activity is made step by step, from planning to evaluation step. In an evaluation step, the activity performance is measured and assessed. It will uncover which parts should be urgently improved. All school's activities are evaluated and judged. So, the improvement is focused on a weak part.

TQM should be considered as a part of Islamic school culture. All school's activities have their own standards and been motivated to reach a school's vision. Daily/habitual activities need to be a written document, making a book of program standards, at a certain time, the activities and documents are evaluated. Teachers, staff, and also students should have a growth mindset to interact and accept new things. One of the Islamic leader's obligations is to make sure the school's activities from academic services to nonacademic services like parking area, security, or canteen, in line with a book of service standard, which is merely made to obtain institutions vision. Continuous improvement becomes a habit and institutional culture. Data and information available in relation to a school's activities become an essential element in continuous improvements since the improvements are the philosophy of TQM in promoting growth mindset towards a school's leader, teachers, staffs, and students.

\subsection{Quality Assurance}

In TQM, quality assurance is an important part. In quality assurance, Islamic schools determine a quality standard that should be met to satisfy a customer and as a point to make continuous improvement. A determined quality standard is expected beyond the government standards. For example, a government requirement for the teacher is a bachelor degree. If an Islamic school has magister or doctor qualification, then the government standard is exceeded. Besides, quality assurance is employed to make sure the school graduates have a sufficient qualification as a school promise.

An Islamic school in an attempt to conduct quality assurance should check whether a school has a manual book of quality in organizing the activities. The manual book of quality, then, is broken down until the specific stages. Standard operating procedure (SOP) is the specific guidance in keeping the activities that should be on track. The degree of a leader, teacher, and staff's obedience on SOP is measured and analyzed to perform continuous improvement.

Quality assurance, however, should be only for document purposes or accreditation purposes, never is implemented in the school's activities. Consequently, this makes a gap between the accreditation score and the real service received by students and parents. If the gap extremely happens, when the level of students/parents' satisfaction is low, but the school's accreditation score is high, the admission number of students is considered. The small amount of admission students is the reflection of the existing condition of the Islamic school.

Therefore, a growth mindset is needed in a top leader, teachers, and staff. It realizes that quality assurance is a must process. It has a purpose of improving a school's performance and graduates. The suitability of promise and reality is an Islamic school's accountability towards society and to Allah the Almighty.

\subsection{The Shift of Mindset from Fixed Mindset to Growth Mindset}

The shift of mindset from a fixed mindset to a growth mindset becomes the primary requirement in responding to a challenge, and the growth mindset can change from a problem into an opportunity. Covey (2010) explains that the change of mindset will cause a significant and fundamental change. The shift of a school mindset at schools is how to make a quality becomes a corporate/school's culture and also individual lifestyle. It will never happen if the old or conservative paradigm is used. It should be changed with a new and obsolete standard. An outdated developed model in improving a school's quality, as Natawidjaja (2005) suggested as follows:

1) Quality First. A leader's attitudes and thoughts should be put a variety as a top priority.

2) Stakeholder-in. A leader's attitudes and thoughts should be intended for stakeholders' satisfaction.

3) The Next Process is Our Stakeholders. A single person who is in charge of school should think that every person who uses the educational service is a satisfied stakeholder.

4) Speak With Data. A person who is in charge of school should use data and analyze the relevant data when the decision is made.

5) Upstream Management. Every decision making at school should involve every person at school (teachers and staff).

This new shift makes the growth mindset dominate in people's mindset at school. The daily activities are situated to promote learning spirit and to anticipate a change. As revealed by Natawidjaja (2005), "speak with data" should be an Islamic school's good tradition in quality management. Therefore, the use of management information systems in all educational standards should be empowered.

An Islamic school should never stop in obtaining faqihfiddin output (Islamic understanding) and Al-Quran memorizers. Moreover, it should complete a school with sufficient facilities and a sophisticated management information system. A school leader should also be aware of an analytical evaluation of academic and non-academic services and upgrade the teacher's and staff's capacity to develop a growth mindset. The final result in quality management reached is to improve an Islamic school's competitiveness in the local and global scope. In brief, an Islamic school can be equal to a local and international public school with an outstanding graduate's competence.

\section{CONCLUSION}

As has been discussed, growth mindset becomes an essential principle in quality management in an Islamic school, like an answer in the challenge of the 4.0 revolution. Islamic schools need to improve their competitiveness not only with similar Islamic schools but also public schools. Islamic schools should not feel satisfied by recognizing the output (students) who memorizes Al-Quran and understand Islamic knowledge (tafaqquh fiddin). However, the Islamic schools should be able to compete with the output from public schools in academic competence. Quality management in Islamic schools should consider the outcomes and how to go beyond the eight standards of national educational standards. Consequently, they should enhance their services with various instruments and facilities which provide sufficient information on an Islamic school's existing condition. An available strategic plan 
and quality documents are urgent to support quality management in Islamic schools. Without a growth mindset, Islamic schools are difficult to develop their institutions to have sufficient competitiveness.

\section{References}

Arcaro, J. (2007). Pendidikan Berbasis Mutu. Yogjakarta: Pustaka Pelajar.

Covey, S. (2010). Tujuh Kebiasaan Manusia Yang Efektif. Jakarta: Bina Rupa Aksara.

Crosby, P.B. (1979). Quality is Free. New York: Mc-Grew Hill.

Dweck, C. S. (1999). Self-Theories: Their Role in Motivation, Personality, and Development. Philadelphia, PA: Psychology Press.

Dweck, C. S. (2006). Mindset: The new psychology of success. New York, NY: Random House.

Dweck, C., \& Master, A. (2009). Self-Theories and Motivation: Student's Beliefs about Intelligence. In K. R. Wentzel \& A. Wigfield (Authors), Handbook of motivation at school. (pp. 123-140). New York, NY: Routledge.

Kasali, Rhenald. (2014). Self Driving, Bandung: Mizan.

Kurniawan, \& Mahrus, E. (2011). Jejak Pemikiran Tokoh Pendidikan Islam. Yogjakarta: Ar-Ruzz Media.

Kodrat, D. (2019). Urgensi Perubahan Pola Pikir Dalam Membangun Pendidikan Bermutu. Jurnal Kajian Peradaban Islam, 2(1), 16.

Mardjun, A. N. (2007). Tantangan Pendidikan Islam Abad XXI. HUNAFA: Jurnal Studia Islamika, 4(1), 23-30.

Mueller, C. M., \& Dweck, C. S. (1998). Praise for intelligence can undermine children's motivation and performance. Journal of personality and social psychology, 75(1), 33.

Natawijaya, R. (2005). Aktivitas Belajar. Jakarta: Depdiknas.

Salis, E. (2002). Total Quality Management in Education. London: Kogan Page.

Saunders, S. A. (2013). The Impact of a Growth Mindset Intervention on The Reading Achievement of At-Risk Adolescent Students. Ann Arbor, MI: ProQuest LLC.

Staiou, E. (2006). Total quality management in engineering education. In Proceedings of the 3rd WSEAS/IASME International Conference on Engineering Education, Vouliagmeni, Greece (pp. 125-130). 